\title{
Rational Usage of Amorphous Varieties of Silicon Dioxide in Dry Mixtures of Glass with Specific Light Transmittance
}

\author{
N. Min’ko ${ }^{(\bowtie)}$ and O. Dobrinskaya \\ Belgorod State Technological University named after V G Shukhov, \\ Belgorod, Russia \\ minjko_n_i@mail.ru
}

\begin{abstract}
The paper studied high-silicon amorphous rocks from the perspective of their application for glass production of different purpose. The results contained data of calculation of dry mixtures for producing heat-protective glass using amorphous varieties of silicon dioxide. The obtained glass specimens were melted and studied for spectral characteristics.
\end{abstract}

Keywords: Amorphous silicon dioxide $\cdot$ Light transmittance $\cdot$ Dry mixture $\cdot$ Heat-protection glass

\section{Introduction}

High-silicon amorphous rocks as raw materials have a wide range of valuable features. Primarily, this is the amorphous (metastable) state of silicon dioxide (Kondrashov and Kondrashov 2013). Moreover, one can distinguish some peculiarities of amorphous varieties that can be regarded as drawbacks (Manevich et al. 2012):

- instability of chemical composition;

- $\mathrm{SiO}_{2}$ is accompanied by other components (up to $40 \%$ ) that can play the role of auxiliary raw materials;

- increased content of aluminum oxides and iron.

One of the main glass spectral characteristics is light transmittance. The main components that affect light transmittance of glass products and that should be strictly controlled are oxides of coloring metals that are encountered in conventional raw materials (dolomite, feldspar concentrate, sands). These compounds include iron oxides; their content in glass is strictly regulated:

- sheet glass - 0.09-0.12\%;

- heat-protective $-0.6-0.7 \%$;

- clear container glass $-0.1 \pm 0.01 \%$;

- brown container glass $-0.8 \pm 0.1 \%$;

- green container glass - not regulated. 
The composition of amorphous varieties of silicon dioxide (Distantov 1976) is characterized by increased content of iron oxides (Table 1), which impedes their wide application in production of glass articles.

Table 1. Variation of chemical composition of amorphous silicic raw materials

\begin{tabular}{|c|c|c|c|c|c|c|c|c|}
\hline \multirow[t]{2}{*}{ Rock } & \multicolumn{8}{|c|}{ Content of oxides [wt.\%] } \\
\hline & $\mathrm{SiO}_{2}$ & $\mathrm{Al}_{2} \mathrm{O}_{3}$ & $\mathrm{Fe}_{2} \mathrm{O}_{3}$ & $\mathrm{CaO}$ & $\mathrm{MgO}$ & $\mathrm{K}_{2} \mathrm{O}$ & $\mathrm{Na}_{2} \mathrm{O}$ & $\mathrm{TiO}_{2}$ \\
\hline Diatomites & $73.0-90.0$ & $3.3-7.5$ & $2.0-5.2$ & $\begin{array}{l}\text { less than } \\
0.6\end{array}$ & $0.6-1.7$ & $\begin{array}{l}\text { less than } \\
1.0\end{array}$ & $\begin{array}{l}\text { less than } \\
0.5\end{array}$ & $\begin{array}{l}\text { less than } \\
0.3\end{array}$ \\
\hline Opokas & $52.1-91.4$ & $2.5-15.4$ & $1.0-5.0$ & $0.43-17.1$ & $\begin{array}{l}\text { less than } \\
2.48\end{array}$ & $0.6-4.0$ & $0.1-1.0$ & $\begin{array}{l}\text { less than } \\
0.2\end{array}$ \\
\hline Pearlites & $68.5-75.3$ & $11.2-16.3$ & $\begin{array}{l}\text { less than } \\
3.0\end{array}$ & $0.5-2.0$ & $\begin{array}{l}\text { less than } \\
1.0\end{array}$ & $1.5-4.0$ & $2.0-6.2$ & $0.1-0.5$ \\
\hline Tripolites & $35.3-86.7$ & $2.5-11.6$ & $0.3-3.4$ & $0.4-31.2$ & $0.2-1.6$ & $0.85-2.1$ & $\begin{array}{l}\text { less than } \\
0.5\end{array}$ & $\begin{array}{l}\text { less than } \\
0.2\end{array}$ \\
\hline
\end{tabular}

Taking into account increased content of iron and aluminum oxides, these rocks can be used as aluminum- or iron-containing raw materials in production of heatprotection glass or dark-glass containers.

\section{Methods and Approaches}

Current work assesses amorphous silicon dioxide (ASD) as aluminum-containing raw material that can partially replace quartz sand and other conventional raw materials (Table 2).

Table 2. Composition of average samples of amorphous silicon dioxide varieties

\begin{tabular}{l|l|c|l|l|l|l|l|l}
\hline \multirow{2}{*}{ Rock } & \multicolumn{7}{|l}{ Content of oxides [wt.\%] } \\
\cline { 2 - 9 } & $\mathrm{SiO}_{2}$ & $\mathrm{Al}_{2} \mathrm{O}_{3}$ & $\mathrm{Fe}_{2} \mathrm{O}_{3}$ & $\mathrm{CaO}$ & $\mathrm{MgO}$ & $\mathrm{K}_{2} \mathrm{O}$ & $\mathrm{Na}_{2} \mathrm{O}$ & $\mathrm{TiO}_{2}$ \\
\hline Diatomite & 87.22 & 6.79 & 2.22 & 0.431 & 1.25 & 1.08 & 0.245 & 0.265 \\
\hline Opoka & 92.47 & 3.38 & 1.32 & 0.506 & 0.712 & 0.88 & - & 0.174 \\
\hline Pearlite & 72.0 & 16.45 & 1.06 & 0.863 & 0.422 & 4.30 & 4.21 & 0.145 \\
\hline Tripolite & 79.93 & 10.99 & 3.17 & 0.838 & 1.81 & 1.99 & 0.273 & 0.687 \\
\hline
\end{tabular}

To conduct experimental studies, the dry mixtures for heat protective glass with ASD were calculated. The glass was melted from the dry mixtures using pearlite. The content of iron oxides in pearlite is insufficient for production of heat-protective glass, which necessitates the introduction of iron containing material such as magnetite.

The glass was melted in an electric kiln with silicon carbide heating elements at maximum melting temperature of $1420{ }^{\circ} \mathrm{C}$. Another batch of glass was melted without pearlite.

Spectral light transmittance in the visible range was measured automatically on SF56 spectrophotometer (Russia). The specimens were prepared by mechanical grinding and polishing on laboratory setups. 


\section{Results}

The results showed that the application of ASD for preparation of dry mixtures allowed reducing number of conventional materials for glass melting (Table 3).

Table 3. Economy of conventional raw materials after replacement by ASD, \%

\begin{tabular}{l|l|c|c|l}
\hline \multirow{2}{*}{ Rock } & \multicolumn{4}{|l}{ Raw material } \\
\cline { 2 - 5 } & Sand & Soda & Creta & Dolomite \\
\hline Opoka & $\mathbf{7 2 . 7}$ & 2.44 & 1.61 & 19.71 \\
\hline Pearlite & 43.8 & $\mathbf{2 0 . 1 5}$ & $\mathbf{3 8 . 7}$ & $\mathbf{4 0 . 3 8}$ \\
\hline Diatomite & 41.7 & 6.5 & 4.08 & 25.14 \\
\hline Tripolite & 27.6 & 7.79 & 7.66 & 27.06 \\
\hline
\end{tabular}

The glass produced in the laboratory differed in color (Fig. 1), which depends on the shift of equilibrium $\mathrm{Fe}^{2+} \leftrightarrow \mathrm{Fe}^{3+}$.

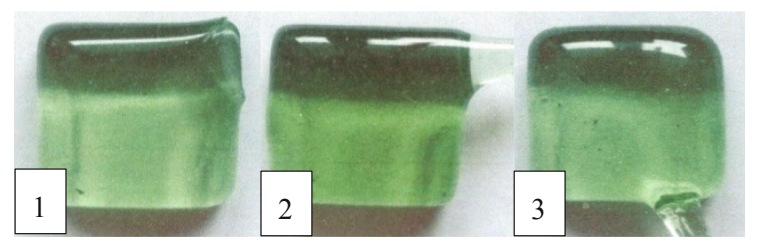

Fig. 1. Specimens of sheet glass: 1 - with pearlite; 2 - with pearlite and magnetite; 3 - with pearlite and magnetite $(+$ coal $)$

We studied spectral characteristics of the glass specimens: sheet glass melted from conventional components; sheet glass with addition of pearlite as aluminum-containing raw material; sheet glass with addition of magnetite (magnetite was reduced by coal) (Fig. 2).

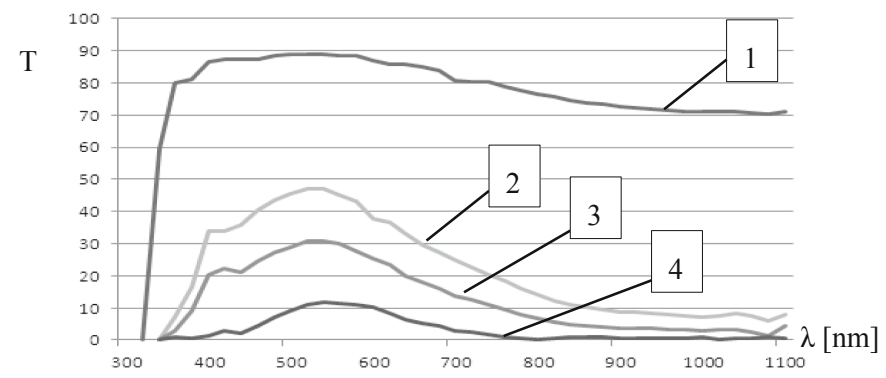

Fig. 2. Spectral light transmittance of sheet glass: 1 - conventional raw materials; 2 - with pearlite; 3 - with pearlite and magnetite; 4 - with pearlite and magnetite (+ coal) 
The data from Table 4 demonstrated that in the visible spectrum, the light transmittance of the glass with application of pearlite differed from glass melted with conventional raw materials. The highest light transmittance was shown by sheet glass melted from conventional raw materials, since the content of iron in quartz sand was minimal $(0.022 \mathrm{wt} \%)$.

Table 4. Light transmittance of sheet glass specimens calculated for the thickness of $10 \mathrm{~mm}$

\begin{tabular}{|c|c|c|c|c|c|}
\hline \multirow[t]{3}{*}{ Specimen } & \multicolumn{4}{|c|}{ Light transmittance $\mathrm{T}[\%]$} & \multirow{3}{*}{$\begin{array}{l}\text { Diathermancy } \\
\text { index }=10^{-1} \\
\mathrm{~T}_{1100}\end{array}$} \\
\hline & \multicolumn{2}{|c|}{$\lambda=570 \mathrm{~nm}$} & \multicolumn{2}{|c|}{$\lambda=1100 \mathrm{~nm}$} & \\
\hline & $\begin{array}{l}\text { As per } \\
\text { equation }\end{array}$ & $\begin{array}{l}\text { As per } \\
\text { nomogram* }\end{array}$ & $\begin{array}{l}\text { As per } \\
\text { equation }\end{array}$ & $\begin{array}{l}\text { As per } \\
\text { nomogram* }\end{array}$ & \\
\hline 1 & 88.6 & 88.1 & 67.4 & 67.7 & 6.7 \\
\hline 2 & 48.4 & 48.8 & 8.4 & 8.2 & 0.8 \\
\hline 3 & 30.8 & 30.5 & 5.1 & 4.8 & 0.4 \\
\hline 4 & 12.3 & 12.0 & 3.7 & 3.2 & 0.3 \\
\hline
\end{tabular}

* - Amosov's nomogram

The heat-protective characteristics are assessed by light transmittance at $\lambda=1100 \mathrm{~nm}$. In the infrared range of the spectrum, the light transmittance of specimens 2, 3 and 4 reduces due to the presence of impurities of $\mathrm{Fe}^{2+}$, which provisions the heat-protective characteristics.

In IR-range, the light transmittance of studied glasses is different (from 3 to 67\%), i.e. high heat-protective properties are possessed by specimens 3 and 4, the IR-light transmittance is $3-5 \%$. However, the production of glass with such content of FeO is unreasonable due to low light transmittance in the visible spectrum. Such dry mixtures can be used for special glass.

\section{Conclusions}

The calculations allowed determining the amorphous varieties of silicon dioxide that could replace most conventional materials in dry mixtures. They were: opoka (as a replacement for quartz sand) for both aluminum- and iron-containing raw materials, and pearlite capable of replacing the biggest amount of soda, creta and dolomite when using it as an iron-containing material.

Additional studies of glass properties produced from dry mixtures with pearlite were required (spectral characteristics, crystallization capacity and impact of redox conditions of melting). Nevertheless, the work showed that pearlite could be used in the technology of heat-protective glass. 
Acknowledgments. The work is realized in the framework of the Program of flagship university development on the base of Belgorod State Technological University named after V.G. Shukhov, using the equipment of High Technology Center at BSTU named after V.G. Shukhov.

\section{References}

Distantov AG (1976) Silicon rocks of USSR. Tatar Press, Kazan

Kondrashov VI, Kondrashov DV (2013) Perspectives of synthesis of industrial compositions of float-glass on the basis of crystalline and amorphous silicon dioxide. GlassRussia. 3:31-33

Manevich VE, Subbotin RK, Nikiforov EA, Senik NA, Meshkov AV (2012) Diatomite as silicacontaining material for glass industry. Glass Ceram 5:34-39

Open Access This chapter is licensed under the terms of the Creative Commons Attribution 4.0 International License (http://creativecommons.org/licenses/by/4.0/), which permits use, sharing, adaptation, distribution and reproduction in any medium or format, as long as you give appropriate credit to the original author(s) and the source, provide a link to the Creative Commons license and indicate if changes were made.

The images or other third party material in this chapter are included in the chapter's Creative Commons license, unless indicated otherwise in a credit line to the material. If material is not included in the chapter's Creative Commons license and your intended use is not permitted by statutory regulation or exceeds the permitted use, you will need to obtain permission directly from the copyright holder. 